\title{
Seashore Paspalum Management for Home Lawn Use in Florida ${ }^{1}$
}

\section{L.E. Trenholm and J. Bryan Unruh ${ }^{2}$}

Seashore paspalum (Paspalum vaginatum Swartz.) has recently become available for use in home lawns, golf courses, and athletic fields. SeaIsle I seashore paspalum is readily available for purchase in retail outlets as either plugs or sod. Many homeowners looking for an alternative to St. Augustinegrass have replanted their lawns with seashore paspalum. While seashore paspalum generally does very well under professional management on golf courses or athletic fields, lack of knowledge on how to properly manage the grass in the home lawn environment may result in problems.

Management of seashore paspalum differs from that for most other warm-season grasses in some key areas. These include:

- Fertilization - how much and how often to fertilize

- Mowing - height and frequency

- Irrigation
- Herbicides - what is safe and what is legal for use on paspalum

- Insect and disease problems

- Establishment requirements

\section{Fertilization}

The best way to fertilize seashore paspalum is to apply small doses of fertilizer regularly throughout the growing season. This is not always feasible in a home lawn environment, but some general principles should be followed.

\section{Nitrogen Source and Rates}

There are essentially no differences in growth or quality of seashore paspalum due to nitrogen source. However, it is important to base application rates on the nitrogen source being used. Different nitrogen sources can include:

- Quick-release sources (water-soluble products)

1. This document is ENH 897, one of a series of the Environmental Horticulture Department, Florida Cooperative Extension Service, Institute of Food and Agricultural Sciences, University of Florida. Original publication date June, 2003. Visit the EDIS Web Site at http://edis.ifas.ufl.edu.

2. L.E. Trenholm, Assistant Professor, Turfgrass Specialist, Department of Environmental Horticulture, Institute of Food and Agricultural Sciences, University of Florida, Gainesville, FL 32611

J. Bryan Unruh, Associate Professor, Turfgrass Specialist, West Florida Research and Education Center, Institute of Food and Agricultural Sciences, Jay, FL. 32565.

All chemicals should be used in accordance with directions on the manufacturer's label.

The use of trade names in this publication is solely for the purpose of providing specific information. UF/IFAS does not guarantee or warranty the products named, and references to them in this publication do not signify our approval to the exclusion of other products of suitable composition.

The Institute of Food and Agricultural Sciences is an equal opportunity/affirmative action employer authorized to provide research, educational information and other services only to individuals and institutions that function without regard to race, color, sex, age, handicap, or national origin. For information on obtaining other extension publications, contact your county Cooperative Extension Service office. Florida Cooperative Extension Service/Institute of Food and Agricultural Sciences/University of Florida/Christine Taylor Waddill, Dean. 
- Slow-release sources (water-insoluble products)

- Coated sources, which have characteristics of both quick-and slow-release products.

If you use a quick-release nitrogen source on seashore paspalum, it is important to not apply too much nitrogen at any one time. Seashore paspalum is very responsive to nitrogen, and it will produce excessive shoot growth when over-fertilized. You want to avoid promoting excessive shoot growth, so applications of quick-release nitrogen should be limited to $1 / 2 \mathrm{lb}$. of nitrogen per 1,000 square feet at any one time. If you apply a slow-release source, or one that has at least $30 \%$ slow-release due to coating, you may use up to $1 \mathrm{lb}$. of nitrogen per 1,000 square feet with each application. You will see less growth or green-up in response to slow-release nitrogen sources on paspalum.

\section{Annual Fertilizer Rates and Schedule}

The amount of nitrogen to apply to seashore paspalum per year depends on your location in the state and your desired level of performance. The range of rates indicated here will produce a healthy lawn, with the lower rates corresponding to a less manicured look than the higher rates.

North Florida: 2-3 lbs. nitrogen per 1,000 square feet annually

Central Florida: 2-4 lbs. nitrogen per 1,000 square feet annually

South Florida: 3-6 lbs. nitrogen per 1,000 square feet annually

Seashore paspalum should be fertilized at regular intervals throughout the growing season for best performance and growth. If you use quick-release sources, fertilize at 30-45 day intervals or at approximately 60-day intervals with slow-release products.

\section{Potassium Needs}

Seashore paspalum has an affinity for uptake of potassium and should have it re-applied at regular intervals. Ratios of nitrogen to potassium should be at
$1: 1$ for paspalum or even at 1:2 where there are stresses such as traffic on the grass.

\section{Other Elements}

Seashore paspalum does not necessarily require inputs of sodium, chlorine, or other components of saline water to grow. Iron can be used very effectively to provide dark green color without shoot growth and should be considered for use in the summer when additional shoot growth may not be advantageous.

As with all grasses, it is recommended that you soil test to determine your lawn's phosphorus needs and choose a fertilizer based on results of this test. If you have a high amount of available phosphorus in your soil, as is the case in much of Florida, select a fertilizer with no more than $2 \%$ phosphorus.

\section{Mowing Needs}

\section{Scalping and Mowing Height}

Seashore paspalum is very susceptible to injury from scalping (removal of too much shoot tissue at one time). Symptoms of scalping may include onset of disease and/or death of the turfgrass. Because use of quick-release nitrogen sources will rapidly stimulate shoot growth in paspalum, be careful that mowing needs and fertilization regimes are coordinated to avoid scalping. Optimal mowing heights for paspalum in home lawns will depend on the type of mower you use. If you use a reel mower, heights may range from $1 / 2$ to $1 \mathrm{inch}$. With a rotary mower, mow from 1.5 to 2 inches. If you mow at heights greater than 2 inches, seashore paspalum will shade itself out and increase thatch production.

\section{Mowing Frequency}

Because of the vigorous growth of seashore paspalum, optimal mowing frequency during the growing season is more than once a week. While this may not be feasible for a home lawn, it will produce a better looking lawn and will reduce the risk of scalping. Also, during the summer months, many cultivars will produce seedheads about every 4-5 days. These seedheads are light-colored and will give the lawn a slightly chlorotic look if you do not mow them off. 


\section{Mower-Type}

In a home lawn, paspalum can be mowed with a rotary mower at 1.5 to 2 inches. For a better, more manicured look, a reel mower should be used at lower heights. Use of a reel mower will produce a better looking lawn with fewer stress-induced problems.

\section{Irrigation}

Seashore paspalum requires water, either from rainfall or irrigation, to remain green. It is considered drought tolerant because it will regrow following drought when water becomes available. Irrigate paspalum the same way any other grass should be irrigated: let the grass tell you when it needs water. Look for signs such as leaf blades folding in half, or foot or tire tracks that remain long after being made. If $30 \%$ of the lawn shows these symptoms, irrigate unless rain is forecast in the next 24 hours.

Apply enough water to wet the root zone and then wait for signs of drought before watering again. This will encourage the roots to grow down into the soil. In most parts of Florida, an established lawn should receive between $1 / 2-3 / 4$ of an inch of irrigation twice per week during the summer in the absence of rainfall. In some very sandy soils, up to 1 inch of water should be applied to maintain adequate moisture levels. Be sure to check the efficiency of your sprinkler system regularly to make sure it is functioning properly and delivering the proper amount of water. For more information on sprinkler system calibration, refer to Edis fact sheet, "How To Calibrate Your Sprinkler System" (LH026), or go to http://turf.ufl.edu.

\section{Herbicides for Use on Seashore Paspalum}

Many herbicides that are used on other grasses will injure seashore paspalum. Of the herbicides that are safe to use, some of them do not have seashore paspalum specifically listed on the label. This means that the herbicide may not legally be used on paspalum. Should the pesticide label state "for use on warm-season turfgrasses" and not specifically exclude seashore paspalum, then one can use the product, but all liability is on the end-user. Following are products that can be used safely and legally.
Broadleaf Weed Control:

Weed-B-Gon ${ }^{\circledR}$ products

Grassy Weed Control:

Quinclorac - Drive ${ }^{\mathrm{TM}}$

Pendimethalin products

Dithiopyr - Dimension ${ }^{\mathrm{TM}}$

Prodiamine -Barricade ${ }^{\mathrm{TM}}$

Sedge Control:

Halosulfuron - Manage ${ }^{\mathrm{TM}}$

\section{Insect and Disease Control}

\section{Insects}

The main insect problems of seashore paspalum are worms, both fall armyworms and sod webworms. These can defoliate leaf tissue rapidly. Control worms with an appropriately labeled insecticide. Mole crickets can cause some damage, but are less of a pest than on bermudagrass.

\section{Disease}

Disease problems on paspalum are common, particularly in home lawns. These problems typically occur in response to an environmental stress such as scalping, over- or under-irrigation, or excess nitrogen application. If you notice disease symptoms, contact your local County Extension office for information on submitting samples or go to the University of Florida Plant Disease Clinics website at http://plantpath.ifas.ufl.edu/pdc/PDClinic.htm

In most cases, use of a broad-spectrum systemic fungicide will stop the spread of the disease. The next step is to encourage regrowth of the grass. This can include verticutting if damage is severe. Verticutting should only be done during times of active growth and will cause some initial injury to the grass. Follow verticutting with application of $1 / 2 \mathrm{lb}$. of quick-release nitrogen per 1,000 square feet to assist in regrowth. It is also important to assess the origin of the problem and ensure that it is corrected so that disease organisms do not become problematic again. 
For instance, if lack of irrigation caused the disease, make sure that your sprinkler system is functioning properly. Similarly, be careful not to scalp paspalum, as this is very likely to induce stress.

\section{Establishment}

\section{Sod}

Establish seashore paspalum sod by following the recommendations for establishment of other warm-season grasses (see EDIS fact sheet "Establishing Your Florida Lawn, LH013). Sodding is more expensive than sprigging or plugging but it produces an "instant lawn." Without proper site preparation and post-installation care, however, the sod can die almost as easily as any other newly planted area. Before buying sod, inspect it carefully to guarantee the absence of weeds, insects, and nematodes. Store the sod in a cool, shady place until you use it. Sod life on pallets during summer is less than 48 hours. Prepare the area to be planted properly (e.g., till it and rake it smooth) and moisten it when you lay the sod. Fit the pieces of sod together as tightly as possible, but do not stretch the sod to fit the area. If you notice cracks between pieces, fill them with topsoil. Tamp or roll the sod to remove air pockets and ensure good soil contact. If the sod is not in contact with the underlying soil, the roots will dry out and die. If the sod is wet but the soil below is dry, the roots will not penetrate below the original layer of sod. Do not let the soil dry out until there is a good union between the sod and the soil surface. After the sod has rooted, light, frequent applications of soil topdressing will help to smooth out the lawn surface. Sodding is expensive, but it is recommended where immediate cover is desired for an aesthetic reason or to prevent soil erosion.

\section{Plugs}

Plugging is the planting of 2- to 4-inch circular or block-shaped pieces of sod at regular intervals. Three to ten times as much planting material is necessary for plugging as for sprigging. When establishing plugs, it is important to achieve full cover as quickly as possible to avoid weed infestation. To encourage plugs to fill in and grow laterally, apply $1 / 4 \mathrm{lb}$. nitrogen per 1,000 square feet at approximately 10 and 20 days after planting. This will help the grass fill in.

Square plugs can be cut from sod with a shovel, axe, or machete, while round plugs are cut with special steel pluggers similar to a bulb planter. The plugs are then placed in corresponding-sized holes made in the soil. These should be planted on 6to12-inch centers. Wider spacing prolongs the establishment phase. They must be tamped or rolled to prevent the lawn from ending up with a tufted appearance. Plugs do not dry out as rapidly as sprigs, and therefore water is not as critical. However, the rate of coverage is slower than if the grass were sprigged or stolonized. Mulching will help improve moisture retention and prevent erosion of the soil between plugs.

\section{The Bottom Line}

So, will seashore paspalum be viable as an alternative turfgrass for home lawn use? Homeowners enjoy the look and feel of the grass and many are eager to try it. If paspalum is to be successfully used in home lawns, the management practices outlined here must be followed. 